\title{
Erosive effects of a posterior mediastinal mass in a 18th to early 19th c. Spanish child mummy
}

DOI:

10.1007/s12024-018-0013-8

\section{Document Version}

Accepted author manuscript

Link to publication record in Manchester Research Explorer

\section{Citation for published version (APA):}

Loynes, R. D., Charlier, P., Perciaccante, A., Gonzalez, M., Begerock, A., \& Bianucci, R. (2018). Erosive effects of a posterior mediastinal mass in a 18th to early 19th c. Spanish child mummy. Forensic Science, Medicine, and Pathology , 14(4), 574-578. https://doi.org/10.1007/s12024-018-0013-8

\section{Published in:}

Forensic Science, Medicine, and Pathology

\section{Citing this paper}

Please note that where the full-text provided on Manchester Research Explorer is the Author Accepted Manuscript or Proof version this may differ from the final Published version. If citing, it is advised that you check and use the publisher's definitive version.

\section{General rights}

Copyright and moral rights for the publications made accessible in the Research Explorer are retained by the authors and/or other copyright owners and it is a condition of accessing publications that users recognise and abide by the legal requirements associated with these rights.

\section{Takedown policy}

If you believe that this document breaches copyright please refer to the University of Manchester's Takedown Procedures [http://man.ac.uk/04Y6Bo] or contact uml.scholarlycommunications@manchester.ac.uk providing relevant details, so we can investigate your claim.

\section{OPEN ACCESS}




\section{Forensic Science, Medicine and Pathology \\ Erosive effects of a posterior mediastinal mass in a 19th c. Spanish child mummy --Manuscript Draft--}

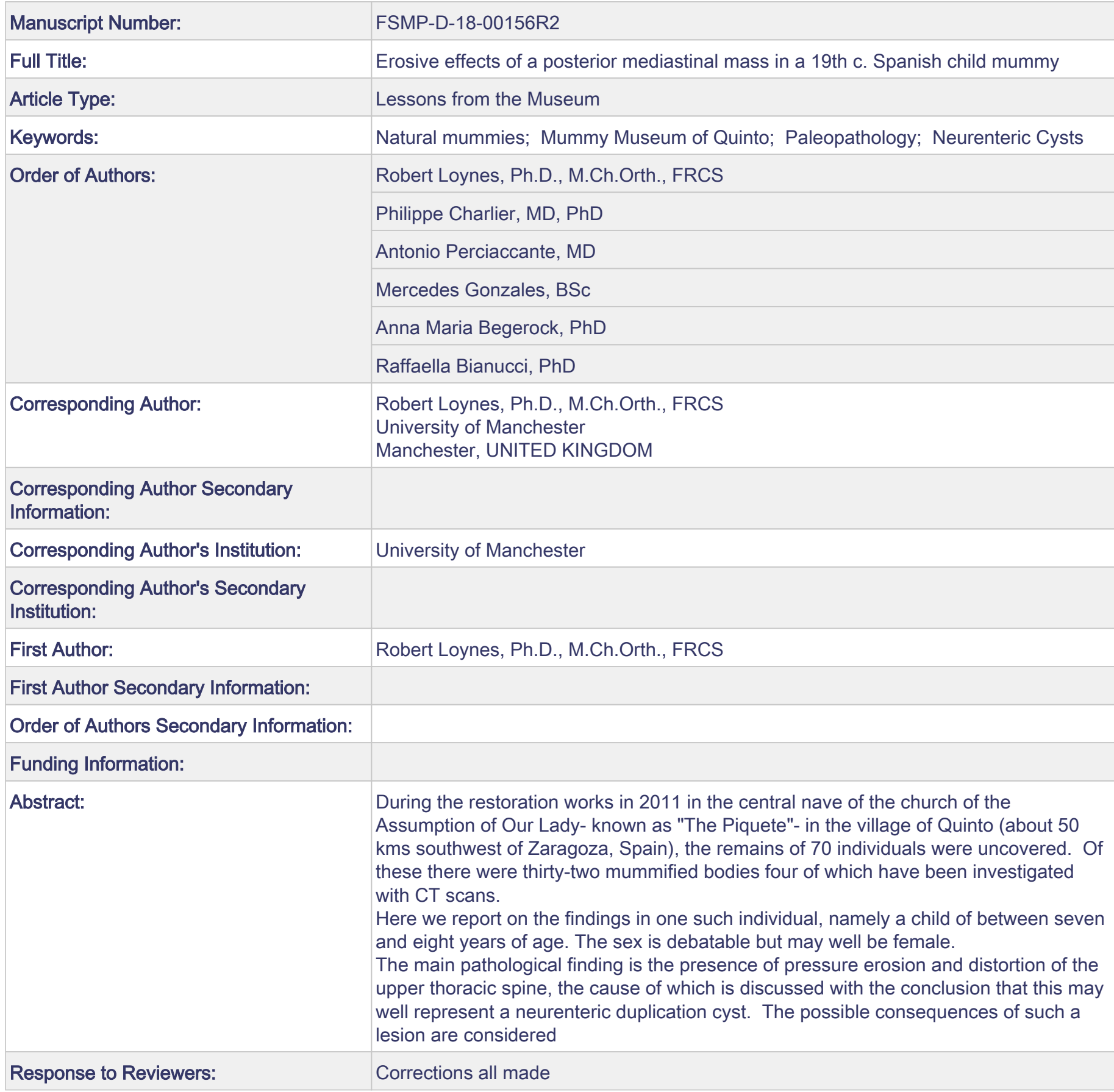




\section{Erosive effects of a posterior mediastinal mass in a 18th to early 19th c. Spanish child mummy}

\section{Loynes R.D., ${ }^{1}$ Charlier P. ${ }^{2-3}$, Perciaccante A. ${ }^{4}$, Gonzalez M. ${ }^{5}$, Begerock A. ${ }^{5}$, Bianucci R. ${ }^{6-8}$}

${ }^{1} \mathrm{KNH}$ Centre for Biomedical Egyptology, University of Manchester, 3.5 Stopford Building, Oxford Road, Manchester M13 9PT, UK; robert.loynes@ manchester.ac.uk

${ }^{2}$ Section of Medical and Forensic Anthropology (UVSQ DANTE Laboratory EA 4498), Montigny-LeBretonneux, France; ph_charlier@yahoo.fr

${ }^{3}$ CASH \& IPES, Nanterre, France.

${ }^{4}$ Department of Medicine, San Giovanni di Dio Hospital, Gorizia, Italy; antonioperciaccante@libero.it ${ }^{5}$ Institute for the Scientific Study of Mummies (IECIM). Madrid, Spain; mgonzalez.iecim@gmail.com; abegerock.iecim@gmail.com

${ }^{6}$ Legal Medicine Section, Department of Public Health and Paediatric Sciences, University of Turin, Italy. raffaella.bianuci@unito.it

${ }^{7}$ Warwick Medical School, Microbiology and Infection Unit, The University of Warwick, United Kingdom.

${ }^{8}$ UMR 7268, Laboratoire d'Anthropologie bio-culturelle, Droit, Etique \& Santé (Adés), Faculté de Médecine de Marseille, France.

Word Count. 1263 


\begin{abstract}
$\underline{\text { Abstract }}$
During the restoration works in 2011 in the central nave of the church of the Assumption of Our Lady- known as "The Piquete”- in the village of Quinto (about $50 \mathrm{kms}$ southwest of Zaragoza, Spain), the remains of 70 individuals were uncovered. Of these there were thirtytwo mummified bodies four of which have been investigated with CT scans.

Here we report on the findings in one such individual, namely a child of between seven and eight years of age. The sex is debatable but may well be female.

The main pathological finding is the presence of pressure erosion and distortion of the upper thoracic spine, the cause of which is discussed with the conclusion that this may well represent a neurenteric duplication cyst. The possible consequences of such a lesion are considered.
\end{abstract}

\title{
$\underline{\text { Key Words }}$
}

Natural mummies; Mummy Museum of Quinto; Paleopathology; Neurenteric Cysts

\section{$\underline{\text { Case Report }}$}

Here we report a probable case of erosion of the spine due a posterior mediastinal mass in an 18th to early 19th century Spanish natural child mummy (ID PQ31) (Figure 1a). This individual along with fourteen other naturally mummified persons represent the core of the newly created Museum of Quinto (ca $50 \mathrm{kms}$ southwest of Zaragoza, Spain).

Sex, age at death, the possible cause of death, and the degree of preservation of the body were established using Multidetector Computed Tomography (Siemens machine with a slice thickness of $1 \mathrm{~mm}$ ). The sex of the body is possibly female as indicated by the presence of a wide sacral notch and a wide sub-pubic angle. (Figure 1b). 
However, direct visualization of the body has shown a flap of soft tissue over the lower anterior abdominal wall that could indicate the remains of a scrotum. The presence of redundant anterior wall skin has also to be considered since remains of a phallus are not found. The age at death, as judged by the dentition - is between 7 and 8 years. [1] (Figure 1c).

The body itself has disintegrated to an extent as a result of a lack of embalming and has subsequently been restored. Unfortunately, restoration included threading of the vertebrae over a wooden "rod".

Nevertheless, parts of the skeleton are approximately in the correct relationship to one another. Most of the epiphyses have disappeared. The upper humeral and upper femoral epiphyses are exceptions. However, the left upper humeral epiphysis is subluxed and the right superior femoral epiphysis is minimally slipped laterally (post-mortem). The right foot lacks the toes, but the left foot remains intact. The hands are clasped together but the right forearm is detached and lies on the right side of the body (Figure 1d). The CT scan images show that the posterior and middle cranial fossae contain desiccated cerebral material (Figure 2a) and remnants of the meninges are seen hanging from the skull vault. Both eyes have been retained within the orbits and are desiccated (Figure $\mathbf{2 b}$ ). The joint between the sphenoid and the basilar part of the occiput has disintegrated allowing disruption of this region. A complete dislocation of the atlanto-occipital and atlantoaxial joints causing separation of the base of the skull, the atlas and the odontoid peg of the axis can be seen. There is, also, dislocation of C2 and C3 (Figure 2 c, d). Further disruption occurs at the C7/T1 level but whether this is related to restoration is impossible to say. Disruption has also occurred within the thorax with dislocation of some of the ribs. There is evidence of structures within the cavity but these are unrecognizable as specific anatomical entities. The main feature of the thorax is the deformed spine (Figure 3a). The continuity of the spine is interrupted at several levels. The upper thoracic spine is abnormal with rotation of 
the vertebrae and distortion of the anterior aspects of the bodies of T2, T3 and T4. This appears to be the result of external pressure anterior to the spine caused by a mass (approximately 3.5 cms in diameter), which is not connected to the spinal canal.

\section{$\underline{\text { Discussion }}$}

The differential diagnosis includes the development of a chronic abscess, aortic dilatation at the level of the arch (i.e. an aneurysm due to congenital syphilis or coarctation), and benign and malignant masses. Congenital syphilis can be excluded since the child does not display the typical signs of the disease (Hutchison's teeth, mulberry molars, periosteal lesions of the long bones, focal destruction and bone loss) [2]. As to coarctation of the aorta, this results in dilatation of the ascending aorta, which is unlikely to cause compressive erosion of the vertebral bodies. Also it leads to "notching of the ribs" as the result of the collateral circulation, a condition which was not obeserved in the CT scan images (Figure 3c) [3]

A chronic abscess would result in a "ragged" appearance of the anterior walls of the vertebral bodies, whereas in this case the margins are smooth [4] (Figure 3d)

It is proposed that these are the erosive effects of a posterior mediastinal mass. A variety of mediastinal masses contain cystic areas and have variable prognoses. [5] Cysts comprise 15\%$20 \%$ of all mediastinal masses [3] and occur in all compartments of the mediastinum. In the living, characterization of these cystic lesions may at times be difficult owing to the variable composition of fluid and associated complications such as haemorrhage or infection. Posterior mediastinal masses include: oesophageal duplication cysts, myelomeningocele and neurenteric anomalies. Primary spinal tumours (benign and malignant) at the thoracic level in children aged between 5 and 10 years include aneurysmal bone cyst, eosinophilic granuloma and osteosarcoma. [6]

Although there is evidence of structures within the cavity these are unrecognizable as specific 
anatomical entities, therefore a retrospective diagnosis concerning the type of cystic lesion and cause within the spinal canal (such as purely neural tumors - e.g. neurofibromata) can be excluded as the "pressure erosion" is anterior. [7]

This leaves us with space occupying lesions anterior to the vertebral body i.e. in the posterior part of the thoracic cavity/posterior mediastinum. The deformity of the vertebral bodies has been caused by a benign lesion as there is no evidence of infiltration.

Oesophageal duplication cysts are developmental in origin and are classified as foregut cysts that are either bronchogenic or neurenteric. [7] Neurenteric cysts are duplication of the alimentary canal associated with a variety of malformations of the spinal column and cord (posterior mediastinal neurenteric cyst). [7] Esophageal duplication cysts are uncommon. Many are asymptomatic, but they may cause dysphagia, pain, or other symptoms owing to compression of adjacent structures. [8] The majority are detected in infants or children usually adjacent to or within the oesophageal wall. [9-13]

Duplication cysts can present with life-threatening complications such as malignant change, ulceration, bleeding, and rupture with consequent mediastinitis and peritonitis. Ectopic gastric mucosa in the cyst may cause haemorrhage or perforation of the cyst, or infection. Duplication cysts are most commonly found in the posterior mediastinum to the right of the distal oesophagus and do not communicate with the lumen. When symptomatic, the symptoms and signs are related to compression of a thoracic-abdominal structure by the enlarged cystic mass. Symptoms and signs include abdominal pain, vomiting, dysphagia, bleeding, anorexia, weight loss, dyspnea, cough, precordial pain, arrhythmias, and, less commonly, obstruction. [9-13] No specific cause of death is shown in this case. However, although benign, duplication cysts in this position can be complicated by respiratory problems including mechanical obstruction and infection. Whilst there is no definitive proof of this, the possibility must be acknowledged. 


\section{References}

1. Scheuer, L., Black, S. Developmental Juvenile Osteology. Academic Press, London: 2000. pp. 61-63, 76-80, 84-88.

2. Tomczyk J , Mańkowska-Pliszka H, Palczewski P, Olczak-Kowalczyk D. Congenital syphilis in the skeleton of a child from Poland (Radom, 18th-19th century, AD). Anthropological Review 2015; 78 (1): 79-90.

3. Aydin E, Aypar E, Oktem A, Ozyuncu O, Yurdakok M, Guvener M et al. Congenital heart defects: the 10-year experience at a single center. J Matern Fetal Neonatal Med. 2018; 18:1-121; https://doi.org/10.1080/14767058.2018.1491029.

4. Raghavan M, Lazzeri E, Palestro CJ. Imaging of Spondyloascitis. Semin. Nucl. Med. 2018; 48(2): 131-147.

5. Jeung MJ, Gasser B, Gangi A, Bogorin A, Charneau D, Wihlm JM et al. Imaging of Cystic Masses of the Mediastinum. RadioGraphics 2002; 22(1): https://doi.org/10.1148/radiographics.22.suppl_1.g02oc09s79

6. Oldham HN, Jr. Mediastinal tumors and cysts (collective review). Ann Thorac Surg $1971 ; 11: 246-275$.

7. Ravindra VM, Eli IM, Schmidt MH, Brockmeyer DL Primary osseous tumors of the pediatric spinal column: review of pathology and surgical decision making.

8. Neurosurg Focus 2016; 41 (2); https://doi.org/ 10.3171/2016.5.FOCUS16155.

9. Fitch SJ, Tonkin IL, Tonkin AK. Imaging of foregut duplication cysts. RadioGraphics 1986; 6:189-201.

10. Demirbilek S, Kanmaz T, Bitiren M, Yücesan S. Mediastinal Neurenteric Cyst in a Child. Ïnönü Üniversitesi Tip Fakültesi Dergisi 2005; 12(1): 41-43.

11. Salo JA, Ala-Kulju K. Congenital esophageal cysts in adults. Ann Thorac Surg 1987; 
$44: 135-138$.

12. Geller A, Wang KK, Dimagno EP. Diagnosis of Foregut Duplication Cysts by Endoscopic Ultrasonography. Gastroenterology 1995; 109: 838-842.

13. Bagwan M R, Reddy S M, Pardeshi C Z, Panicker S, Kumar K. Neurenteric Cyst of Posterior Mediastinum in an Infant: Case Report. Int J Sci Stud 2016; 3(11): 280-283. 


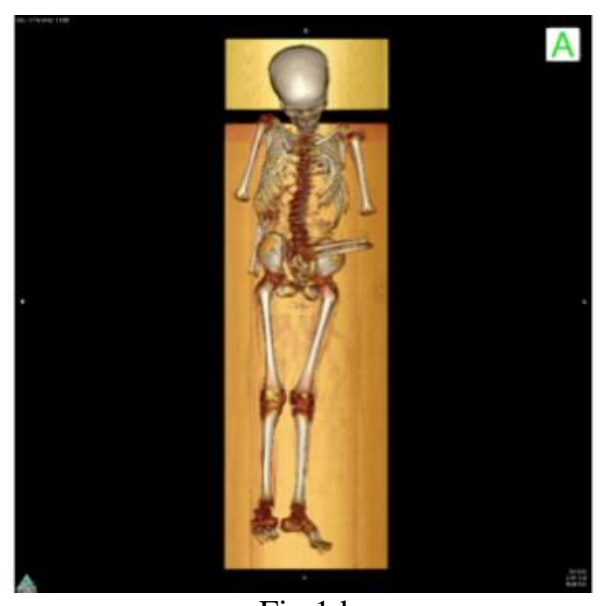

Fig 1d

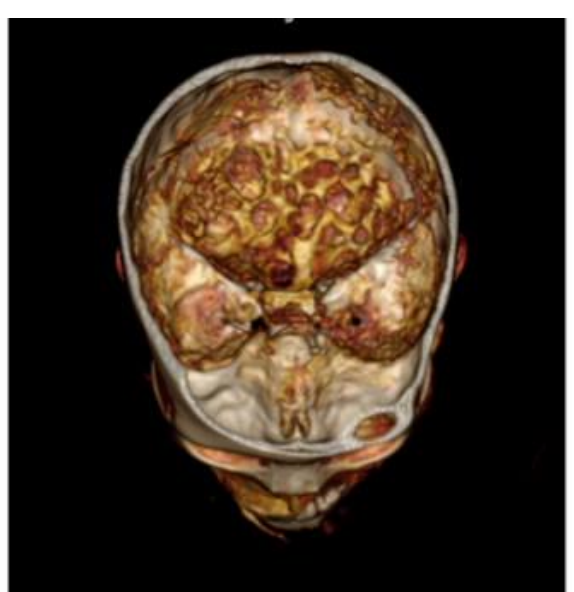

Fig 2a

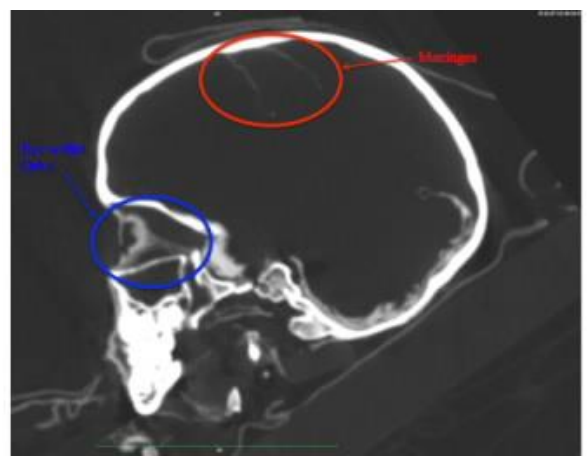

Fig $2 b$

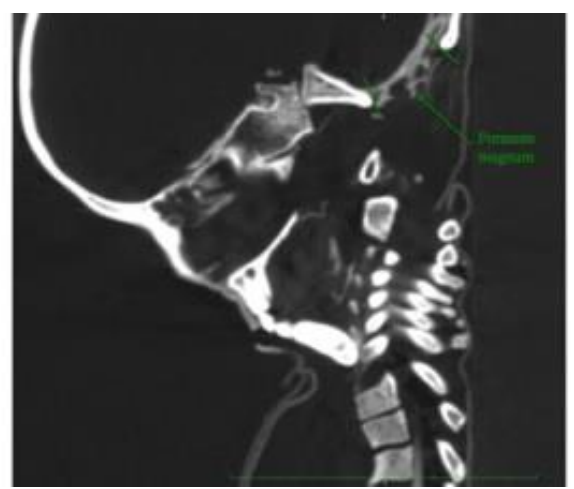

Fig 2c 


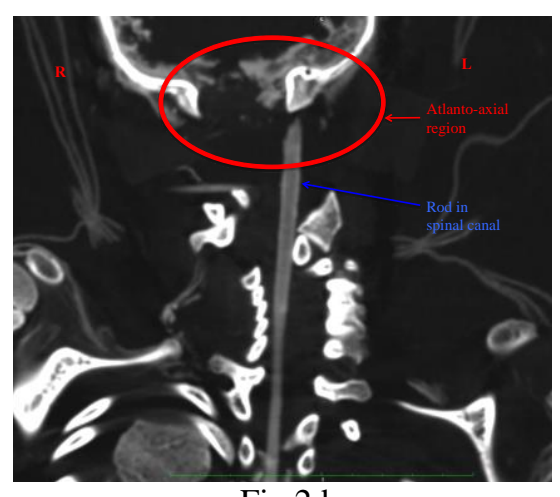

Fig 2d

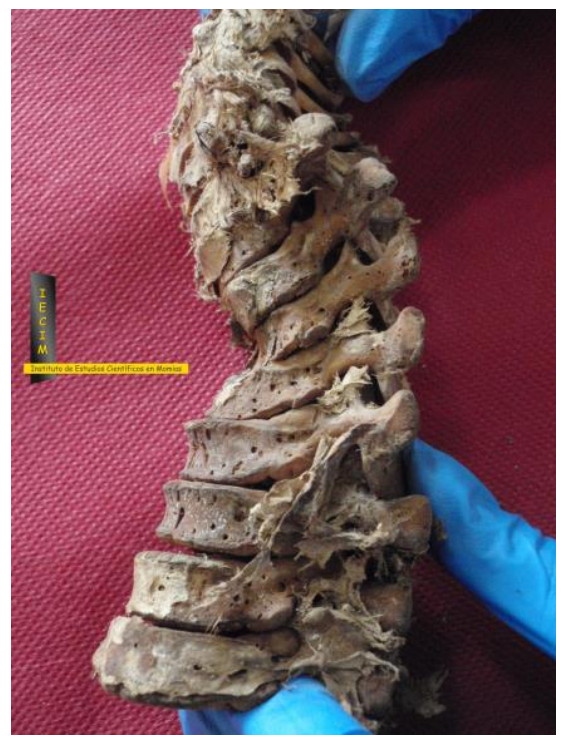

Fig 3a

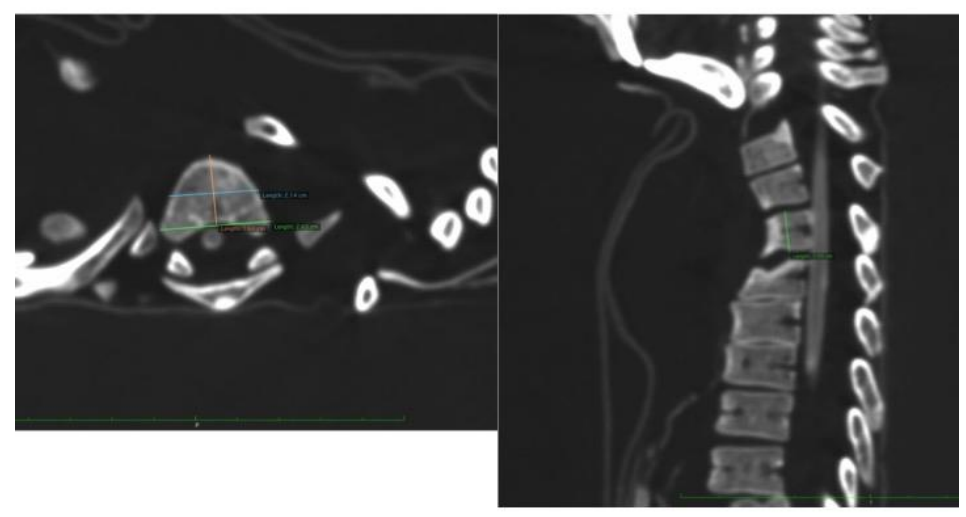

Fig $3 b$ 


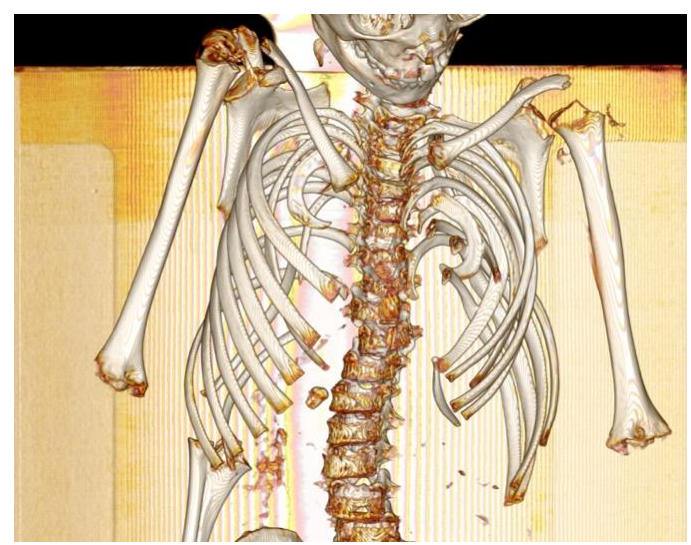

Fig 3c

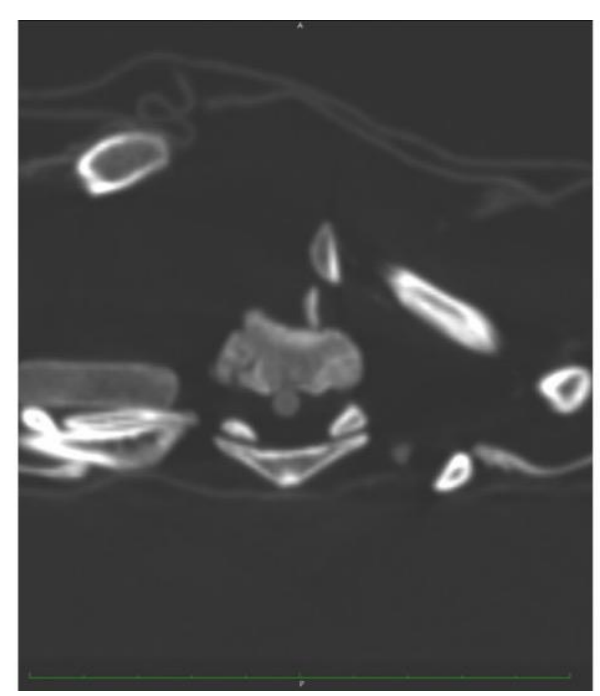

Fig 3d

\section{Figure captions}

Figure 1- a. Child mummy PQ 31 was buried wearing a brown sheep wool Franciscan cassock and monastic cloak; b. Wide subpubic angle; c. Age at death can be placed between 7- and 8 -years -old (the central incisors had erupted but the lateral incisors had not); $\mathbf{d}$. the overall state of preservation of the body is poor and has resulted in an almost complete skeletisation.

Figure 2- a. Desiccated cerebral material; b. Remnants of meninges and retained eye globes; $\mathbf{c} \& \mathbf{d}$. A wooden "rod" inserted in the spinal canal and disruption of C2\&3;

Figure 3- a. Thoracic spinal deformity; b. Spinal deformity caused by pressure ANTERIOR to the vertebrae; c. Ribs without "notching"; d. Anterior spinal body deformity. 